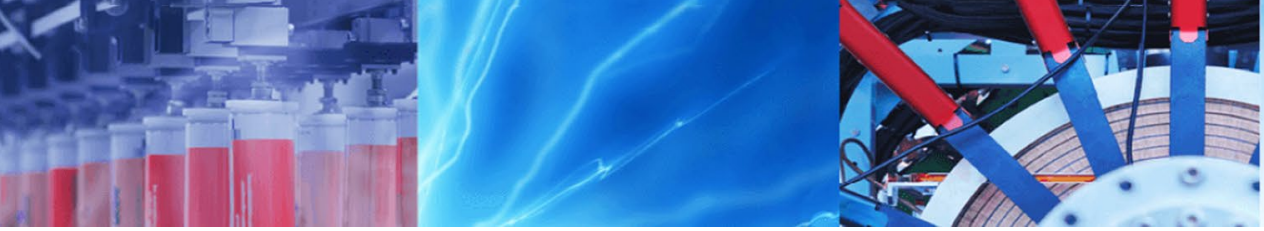

Research Article

\title{
Drivers and responses to climate variability by agro-pastoralists in Kenya: the case of Laikipia County
}

\author{
Godfrey O. Atsiaya ${ }^{1} \cdot$ Oscar I. Ayuya ${ }^{1} \cdot$ Lenah W. Nakhone $^{2} \cdot$ Job Kibiwot Lagat $^{1}$
}

(c) Springer Nature Switzerland AG 2019

\begin{abstract}
This paper examines factors influencing the choice of response strategies and the actual strategies smallholder farmers use to respond to the effects of climate variability in transitional climatic zones of Africa, specifically Laikipia West SubCounty in Kenya. Data for this study were collected from 392 randomly selected smallholder farmers, using a structured questionnaire. The study used principal component analysis to group together related strategies that farmers used to respond to the effects of climate variability, which resulted into seven groups of responses. Majority of farmers at $97.5 \%$, $85 \%$ and $74.1 \%$, respectively, used cultural practices, diversification practices and risk reduction practices. Intensification practices followed by $69.3 \%$ while terraces crop and herd management and new breeds were the least adopted at $27 \%$, $13.2 \%$ and $9 \%$, respectively. Multivariate probit model was then used to examine the factors influencing smallholder farmers' choice of response strategies to effects of climate change. The results indicated that access to weather information had a strong effect on use of risk management strategies at $74 \%$ and intensification strategies at $49 \%$. Increase in level of education and exclusive dependence on agriculture increased the probability of introducing new breeds by $30 \%$ and $53 \%$, respectively, while access to extension services increased use of terraces by $42 \%$. Strong local institutions that facilitate access to information and credit are likely to initiate changes in key household characteristics, which positively affect response to effects of climate variability. Policies should aim to strengthen local institutions that enhance access to information and credit services. There is need for investment in the provision of affordable and quality education, relevant demand-driven extension services that provide localized response solutions.
\end{abstract}

Keywords Multivariate probit · Principal component analysis · Climate variability · Arid and semiarid lands · Agropastoralism · Response

\section{Introduction}

Agro-pastoralists in most of the sub-Saharan countries have been affected by climate variability. This is caused by a combination of factors, which include widespread poverty, dependence on natural resources, over-dependence on rain-fed agriculture, conflicts and negligence from the government [5]. Agriculture is the main economic activity that supports the livelihoods of millions of people in Africa. This has led to most of the population become vulnerable to effects of climate variability, which has negative effects on agricultural productivity, thus the need for smallholder farmers to devise adaptation measures [31]. The arid and semiarid lands (ASALs) require special attention if Kenya is to achieve sustainable economic development. The ASALs cover more than $80 \%$ of the country's land mass and support about $70 \%$ of the national livestock population, valued at an estimated KShs 70 billion [41]. ASALs are largely used for agro-pastoralism, extensive livestock production

Godfrey O. Atsiaya, goddyatsiaya@gmail.com; Oscar I. Ayuya, ingasiaoa@gmail.com; Lenah W. Nakhone, lenahnakhone@gmail.com; Job Kibiwot Lagat, jlagats@gmail.com | ${ }^{1}$ Department of Agricultural Economics and Agribusiness Management, Egerton University, P.O. Box 536-20115, Nakuru, Kenya. ${ }^{2}$ Department of Crops Horticulture and Soils, Egerton University, P.O. Box 536-20115, Nakuru, Kenya.

SN Applied Sciences (2019) 1:827| https://doi.org/10.1007/s42452-019-0849-x

Received: 15 February 2019 / Accepted: 27 June 2019 / Published online: 4 July 2019 
and wildlife. The economic impact of these climate change threats to the country is enormous.

In the ASALs, there is widespread livestock and crop production risks due to climate variability. In many dry regions, most agricultural households are pastoralists or agro-pastoralists who struggle to cope with current climate variability. The vulnerability of pastoral communities to climate change is higher due to the synergic effect of inadequate health services, inadequate infrastructure, poverty, lack of alternative means of income, inadequate public awareness of disease risks and illiteracy [11]. Diverse methods of mitigation have been adopted by pastoralists and agro-pastoralists including grazing management practices. Feed availability and seasonal fluctuations influence the appropriate method of response, which has an implication on the kind of property rights that can be attached to the resources [9]. These areas have naturally high reliance on climate-sensitive activities coupled by marginalization, regular food crises and water scarcity, rapid population growth and limited economic and institutional capacity to cope with climate variability [14]. Thus, response is an urgent priority for farm households to reduce the negative effects of climate variability because the livelihoods of many low-income households are likely to suffer from declining food production [28].

Smallholder farmers in Kenya, as elsewhere in the world, use a range of options to respond to the negative effects of climate variability $[13,40]$. However, despite the benefits of response strategies and the efforts made by stakeholders to encourage farmers to invest in them, it is still not clear how farmers respond and factors that influence the selection of the response strategies. This necessitates the need for a proper understanding how farmers respond and the factors that influence their response. This will help policy makers and other stakeholders in knowing the appropriate strategies to promote in dealing with effects of climate variability. From the above discussion, we first seek to identify the response strategies farmers use to respond to the effects of climate variability. Secondly, we determine the factors that influence the choice of the response strategies. To achieve these objectives, we use a micro-level data set of smallholder farmers in Kenya.

This paper contributes to the literature through the following ways. First, we focus on arid areas, which are the hardest hit by effects of climate variability. This departs from high potential areas focused by earlier researchers $[1-4,40]$ which do not face extreme climatic events that occur in the arid areas. Secondly, we also focus on a comprehensive approach combining crop and livestock and factors influencing response and the real response strategies used. This is different from previous studies, which focused on either crops or animal response strategies in isolation or separately $[21,22,27]$ which could potentially mask some important information that may result from the correlation between the crop and livestock strategies. Lastly, we acknowledge that the decision to adopt response practices is interdependent and farmers in arid areas typically use multiple strategies to deal with climate variability. This is unlike other studies which focused on one or two isolated responses using single adoption models [17, 32, 36,37 ] which may conceal some important information that arise from the correlations that exist when selecting the various response strategies. A multivariate econometric approach is used to take care of any existence of unobservable household-specific factors that affect choice of several adaptation options. We also focus on Kenya where very few studies have been carried out on response to climate variability in the dry lands.

\section{Methods}

\subsection{The study area}

The study area was Laikipia West Sub-County, Laikipia County, Kenya. The area was chosen because of the fragile environment prone to fluctuations in climatic conditions. The effects of recurrent droughts, combined with the low productivity of small and uneconomical land holdings, have aggravated the severity of land degradation, with repercussion on the livelihoods of many local communities. Farmers are trying to adjust in order to continue farming with the challenge of climate variability. The aim of the study was to know how the farmers have responded and the factors affecting their responses.

The study area is located between latitudes $0^{\circ} 17^{\prime} \mathrm{S}$ and $0^{\circ} 45^{\prime} \mathrm{N}$ and longitudes $36^{\circ} 15^{\prime} \mathrm{E}$ and $37^{\circ} 20^{\prime} \mathrm{E}$, occupying an area of approximately $9666 \mathrm{~km}^{2}$. The county extends from the western foot of Mount Kenya to the northeastern base of the Aberdare Ranges. It stretches widely northwards and descends toward the Rift Valley in the northwest with spectacular complex of fault-line volcanic ridges and escarpments as shown in the map of the study area (Fig. 1).

The altitude ranges between 1600 and $2300 \mathrm{~m}$ above sea level on a dry land and semiarid plateau. The long rains occur in April-May, the continental or middle rains in August and November, and a pronounced dry season in January-March. The average annual rainfall varies from 400 to $750 \mathrm{~mm}$ across the county, with higher values observed at the foot of both Mt. Kenya and the Aberdare Range. The human population in the county was 399,227 persons based on the 2009 census. The growth rate was $3.9 \%$ between 1989 and 1999 as compared to the national average of $2.4 \%$ [23]. 
Fig. 1 Map of the study area. Source: World resource center (2013)

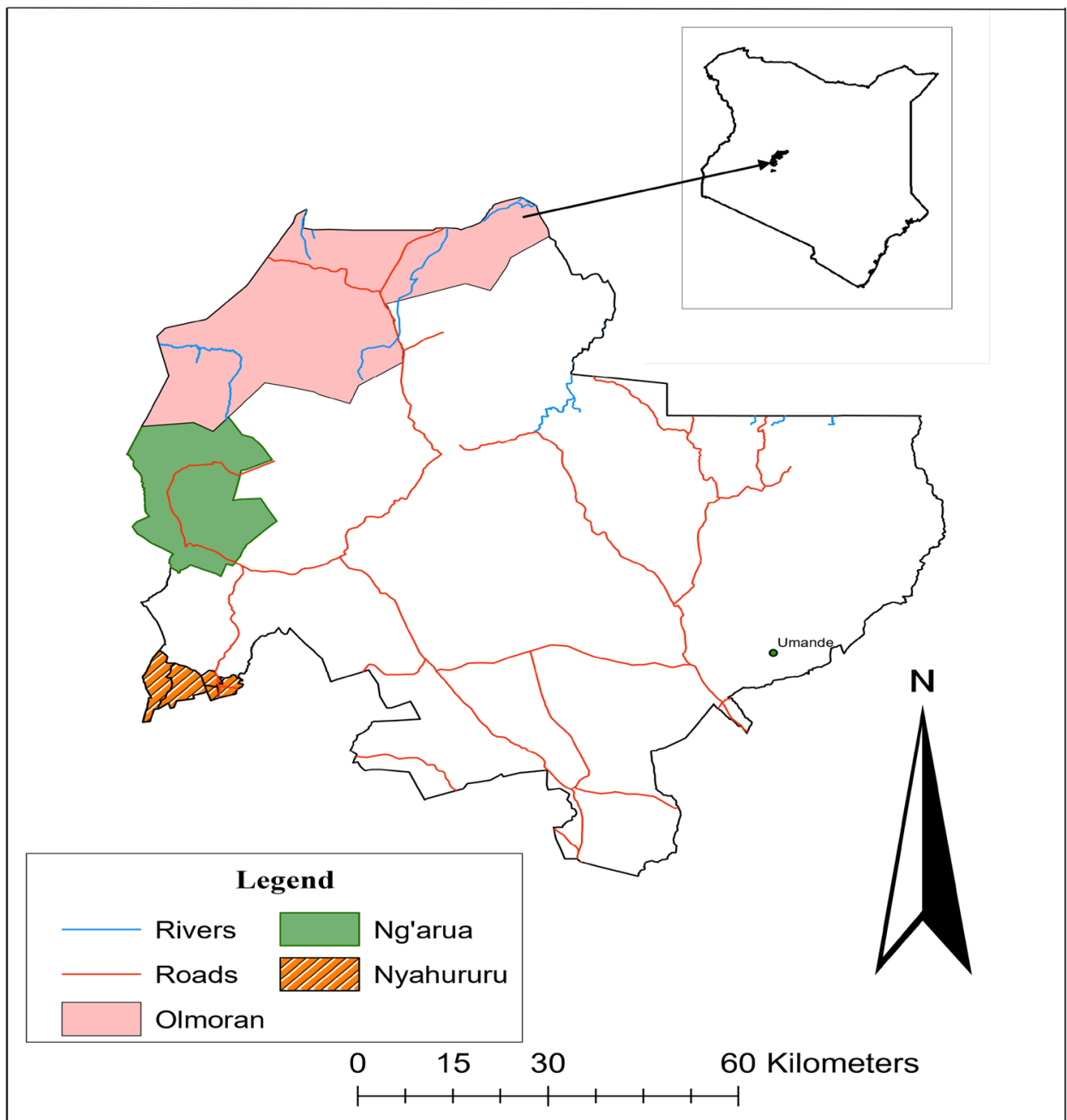

\subsection{Sampling procedure and sample size determination}

The study used a multi-stage sampling technique. Laikipia County was selected purposefully because of its vulnerability to climate variability. Laikipia West Sub-County was selected purposefully because of the fragile environment and vulnerability of the area to drought. Three wards Nyahururu, $\mathrm{Ng}$ 'arua and OI Moran were purposefully selected for the study. Finally the households were randomly selected from a list of households provided by the subcounty Agricultural offices.

A sample of smallholder farmers was taken as representative of the county's smallholder farmers population. The target population was the maize, cattle and goat farmers. The population data were obtained from the area agricultural offices in the three selected wards as 19,219 farm households. The sample size was determined using the following formula by Bowley's [10] quoted in Nzelibe [30] proportion sample formula assuming a $95 \%$ confidence interval as shown:
$S_{\text {total }}=\frac{N}{1+N(e)^{2}}$

where $S_{\text {total }}=$ total sample size of all respondents; $\boldsymbol{N}=$ total population of farming households in Laikipia west district $(19,219)$ (Sub-County agricultural offices); $1=$ constant; $\boldsymbol{e}=$ error term (5\%).

Hence replacing the values into the formula gives

$S_{\text {total }}=\frac{19219}{1+19219(0.05)^{2}}=391.844$

$S_{\text {total }} \approx 392$

The population data for the three wards were Nyahururu $(11,581)$, Ng'arua (4683) and OI Moran (2955); therefore, the sample size for each ward was calculated using probability proportional to size from the identified wards as shown.

$\frac{p}{N} \times S_{\text {total }}$

where $p=$ population of the individual ward; $N=$ total population of the three wards; $S_{\text {total }}=$ total sample size (392). 
Table 1 Sample size for selected wards

\begin{tabular}{lcc}
\hline Ward & Population & $\begin{array}{c}\text { Number } \\
\text { sampled }\end{array}$ \\
\hline Nyahururu & 11,581 & 236 \\
Ng'arua & 4683 & 96 \\
Ol Moran & 2955 & 60 \\
Total & 19,219 & 392 \\
\hline
\end{tabular}

This gives the sample sizes for the three wards as shown in the Table 1.

\subsection{Analytical technique}

First, crop and livestock response strategies used in Laikipia west were identified and grouped into heterogeneous groups by use of principal component analysis. The components were rotated using orthogonal rotation (varimax method) so that smaller number of highly correlated practices would be put under each component for easy interpretation and generalization about a group. The result of the rotation was seven principal components from a possible 20 extracted with eigenvalues $>1$ following the Kaiser's criterion. Principal component analysis was useful in reducing the dimensionality of data without loss of much information. This was important as it allowed determination of the relationship between strategies based on usage and subsequent analysis by fitting the groups into the model and reaching conclusions. The approach is superior to the use of conventional grouping of practices which would make it difficult to conclude about a group in cases where few practices could represent the entire group (Table 2).

The practices were grouped using principal component analysis with iteration and varimax rotation in the model represented as shown below:

$Y_{1}=a_{11} x_{12}+a_{12} x_{2}+\cdots+a_{1 n} x_{n}$

$Y_{j}=a_{j 1} x_{j 1}+a_{j 2} x_{2}+\cdots+a_{j n} x_{n}$

where $Y_{1}, Y_{2} \ldots Y_{j}=$ principal components which are uncorrelated; $a_{1}-a_{n}=$ correlation coefficient; $X_{1}, X_{2}, X_{n}=$ factors influencing use of a particular strategy.

After grouping the response strategies, multivariate probit model was then used to model the factors influencing the choice of response strategies to effects of climate variability. Multivariate probit model simultaneously models the influence of the set of explanatory variables on each of the different adaptation measure while allowing the unobserved and unmeasured factors (error terms) to be freely correlated $[19,20]$. Complementarities (positive correlation) and substitutability (negative correlation) between different options may be the source of the correlations between error terms or the existence of unobservable household-specific factors that affect choice of several adaptation options but are not easily measurable such as indigenous knowledge. The correlations are taken into account in the multivariate probit model. Thus, the adoption decision is inherently multivariate and attempting univariate modeling excludes useful economic

Table 2 Definition of variables that are used in the study

\begin{tabular}{|c|c|c|c|}
\hline Variables & Definition & Measurement & Expected sign \\
\hline \multicolumn{4}{|l|}{ Dependent variable } \\
\hline Response & number of strategies used per farmer & Continuous & \\
\hline WTP & Farmers willingness to pay & $1=$ Yes, $0=$ No & - \\
\hline \multicolumn{4}{|l|}{ Explanatory variables } \\
\hline Age & Age of household head & Years & $+/-$ \\
\hline Credit & Access to credit for the use of adaptation strategies & $1=$ Yes, $0=$ No & + \\
\hline Gender & Gender of household head & $1=$ Male, $0=$ Female & $+/-$ \\
\hline Education & Education level of household head & Years spend in school & + \\
\hline Household size & Total number of members of the household & Number & $+/-$ \\
\hline Land size & Size of land owned by the household & Acres & + \\
\hline Occupation & Whether respondent mainly into farming or not & $1=$ Yes, $0=$ No & $+/-$ \\
\hline Extension & Number of visits received from any extension & Number & + \\
\hline Distance to market & Distance to the main market & Kilometres & $+/-$ \\
\hline Group membership & Membership to a group & $1=$ Yes, $0=$ No & + \\
\hline Weather information & Access to weather information & $1=$ Yes, $0=$ No & + \\
\hline Crop income & Income from sale of maize & Continuous & $+/-$ \\
\hline Wards & Ward dummies with Ward 1 as reference category & $1=$ Yes, $0=$ No & $+/-$ \\
\hline
\end{tabular}


information contained in interdependent and simultaneous adoption decisions. Based on this argument, the study adopted multivariate probit (MVP) econometric technique to simultaneously model the influence of the set of explanatory variables on each of the different strategies, while allowing the unobserved factors to be freely correlated [7, 8 , 24]. The correlation may be positive correlation or negative correlation between different strategies [7, 8]. Correlation coefficients and a likelihood ratio test was carried out to see the suitability of the model.

The model is specified as follows:

$Y_{i m}^{*}=\beta_{m} X_{i m}+\varepsilon_{i m}$

where $Y_{i m}^{*}(m=1, \ldots, k)$ represents the unobserved latent variable of adaptation strategies adopted by the $i$ th farmer. $(i=1, \ldots, n), k$ is the strategies adopted by the farmer. $X_{i m}$ is a $1 \times k$ vector of observed variables that affect the strategy adoption decision, the variables include household socioeconomic, institutional factors, willingness to pay and climate-related factors. $\beta_{m}$ is a $k \times 1$ vector of unknown parameters to be estimated $\varepsilon_{i m}, m=1, \ldots, M$ are the error terms distributed as multivariate normal, each with a mean of zero, and variance-covariance matrix $V$, where $V$ has values of 1 on the leading diagonal and correlations. Equation (3) is a system of $m$ equations as shown in Eq. (2)

$Y_{1}^{*}=X_{1} \beta_{1}+\varepsilon_{1} y_{1}=1$ if $Y_{1}^{*}>0 \quad Y_{1}=0$ otherwise

$Y_{n}^{*}=X_{n} \beta_{n}+\varepsilon_{n} y_{n}=1$ if $Y_{n}^{*}>0 \quad Y_{n}=0$ otherwise

\section{Results and discussion}

This section presents the results obtained from the collected data and the comprehensive discussion of the results. Reliability and quality of the results depended on the respondent's willingness to respond and ability to remember. Use of some response strategies may have been enhanced by promotion of the strategies in the area. Language barrier also was a problem. These challenges were overcome by using local extension staff in order to enhance the trust of respondents hence their willingness to respond. This also solved the problem of language barrier, as the extension staff understood the local language.

\subsection{Principle components for crop and livestock response strategies to climate change}

Table 3 presents a summary of some of the important variables used in the study. Males at $64 \%$ headed majority of the respondent households while females headed $35 \%$ of the households. $58 \%$ had primary education, $20 \%$ had informal education and $12 \%$ had secondary education while only $9 \%$ had tertiary education. Majority of the
Table 3 Descriptive statistics

\begin{tabular}{llc}
\hline Variables & Description & Percentage \\
\hline Gender & Male & 64.47 \\
Education & Female & 35.53 \\
& Informal & 20.56 \\
& Primary & 57.87 \\
& Secondary & 12.18 \\
& College & 6.09 \\
Occupation & University & 3.30 \\
& Farmer & 46.19 \\
Marital status & Others & 53.81 \\
& Married & 71.57 \\
& Single & 10.66 \\
& Divorced & 2.28 \\
& Widowed & 15.48 \\
\hline
\end{tabular}

respondents had other sources of income apart from agriculture at $54 \%$, while $46 \%$ exclusively depend on agriculture. Majority of the respondents were married at $71 \%$ and only $11 \%$ were single.

Table 4 contains principal components with factor loadings for each variable. The results indicate that 7 PCs explained $66.75 \%$ of total variability in the dataset. According to De Bruin et al. [12], Kaiser-Meyer-Olkin measure of sampling adequacy (KMO) is a measure that varies between 0 and 1 , and values closer to 1 are better. A value of 0.6 is a suggested minimum. The Barnett's test of sphericity tests the null hypothesis that the correlation matrix is an identity matrix. These tests together provide a minimum standard, which should be passed before a principal components analysis should be conducted. The KMO value of 0.662 and the Bartlett's test of sphericity with an associated $p$ value of $<0.001$ indicates that I can proceed with PCA. This presents a good fit indicating that the PCA results highly explained the data. A closer look at each column of Table 4 helps us to define each component according to the strongly associated variables. The first component explains $17 \%$ variance and is correlated with increased use of organic fertilizers, early planting, water harvesting and irrigation, replanting fenced paddocks, crop rotation and intercropping. Thus, the component represents cultural practices. The second component explains $12 \%$ variance and is correlated with reduction in herd, increase herd, adaptable species and keeping of browsers. The component can be viewed to represent risk reduction practices. The third component explains $10 \%$ variance and is correlated with zero grazing, improved fodder and mulching; hence, the component represents intensification practices. The fourth component explains $9 \%$ variance and is correlated with staggering planting dates and new farm animals; thus, it represents crop and 
Table 4 Principal component analysis for crop and livestock response strategies

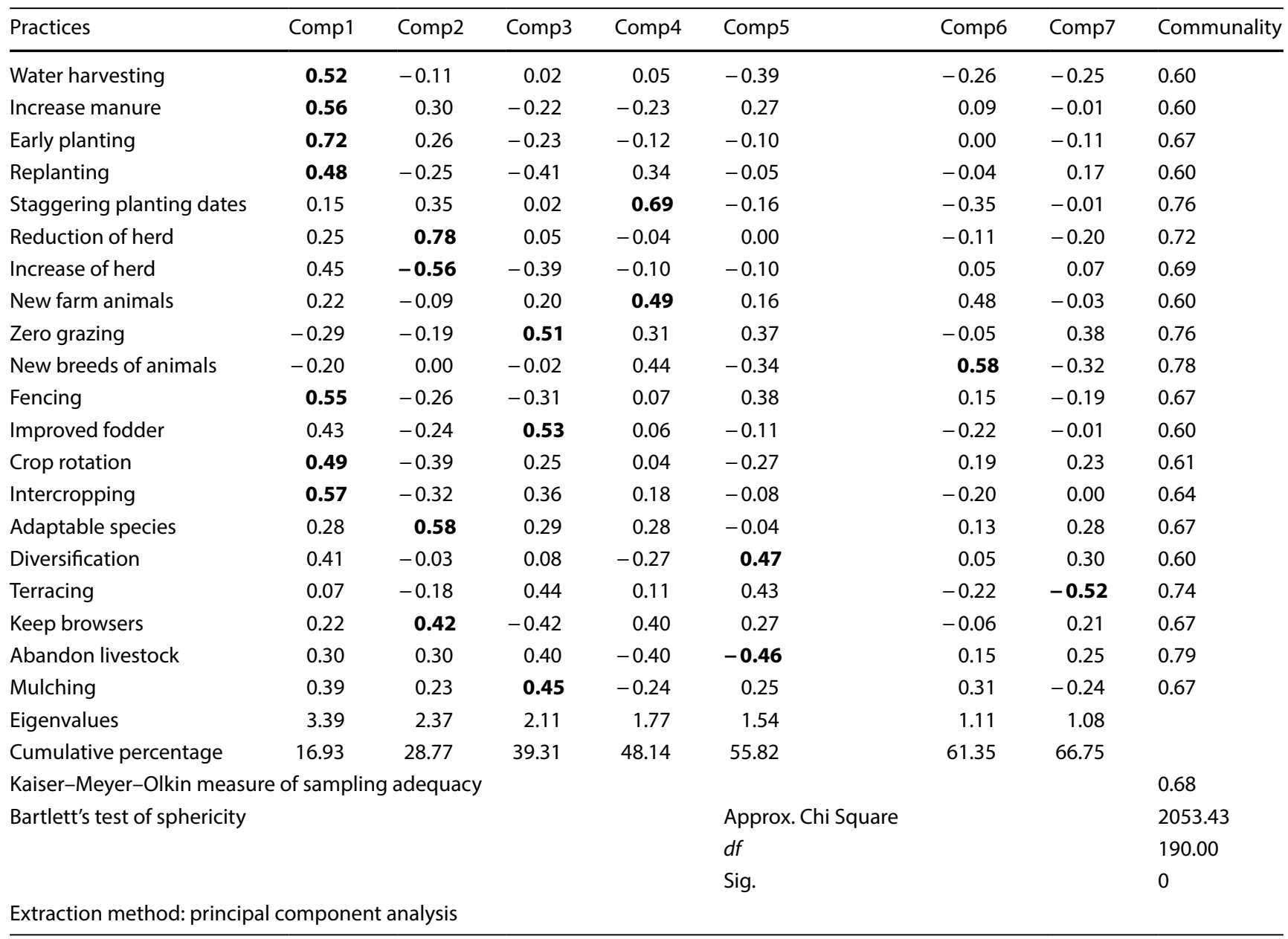

The columns indicated in bold shows the component to which a particular practice falls into

herd management practices. The fifth component explains $8 \%$ and is correlated with diversification and abandoning livestock keeping. This can be viewed as diversification strategies. The sixth component explains $6 \%$ and is correlated with new breeds. The last component explains 5\% and is correlated with use of terraces; hence, the groups formed are: cultural practices, risk reduction practices, intensification practices, crop and herd management practices, diversification practices, new breeds and use of terraces. The communality column shows the total amount of variance of each variable retained in the PCs. For the interpretation of the principal components small values indicate variables that do not fit well with the factor solution and should possibly be dropped from the analysis, variables with high factor loadings and high communality of 0.6 and above were considered from the rotated factor matrix.

Table 5 presents the descriptive statistics of composition of each component (response strategies). Majority of farmers at $97 \%, 85 \%$ and $74 \%$, respectively, used cultural practices, diversification practices and risk reduction practices. These practices may be considered as basic practices that are less technical and mostly do not require much formal expert knowledge, hence can be carried out by many farmers. Intensification practices followed by $69 \%$ can be attributed to extension messages and training. Terraces crop and herd management and new breeds were the least adopted at $27 \%$ and $13 \%$ and $9 \%$, respectively. These strategies may be constrained by access to technical knowledge, land availability and substantial financial investment to implement, hence only few farmers who can access one of the above are able to implement them. This explains the low level of adoption among the households.

\subsection{Socioeconomic and institutional factors that influence farmers' response to effects of climate variability}

To respond to climate change and reduce its negative effects, the farmers in the study area use a combination 
Table 5 Crop and livestock components, respective practices and adoption percentage

\begin{tabular}{|c|c|c|c|}
\hline \multirow[t]{2}{*}{ Component } & \multirow[t]{2}{*}{ Practices } & \multicolumn{2}{|c|}{ Percentage } \\
\hline & & Adopters & Non adopters \\
\hline \multirow[t]{7}{*}{ Cultural practices } & Increased use of organic fertilizers & & \\
\hline & Early planting & 97.50 & 2.50 \\
\hline & Water harvesting and irrigation & & \\
\hline & Replanting & & \\
\hline & Fenced paddocks & & \\
\hline & Crop rotation & & \\
\hline & Intercropping & & \\
\hline \multirow[t]{4}{*}{ Risk reduction practices } & Reduction of herd & & \\
\hline & Increase herd & & \\
\hline & Adaptable species & & \\
\hline & Keep browsers & 74.10 & 25.90 \\
\hline \multirow[t]{3}{*}{ Intensification practices } & Zero grazing & & \\
\hline & Improved fodder & 69.30 & 30.70 \\
\hline & Mulching & & \\
\hline \multirow{2}{*}{$\begin{array}{l}\text { Crop and herd management } \\
\text { practices }\end{array}$} & Staggering planting dates & & \\
\hline & New farm animals & 13.20 & 86.80 \\
\hline \multirow[t]{2}{*}{ Diversification practices } & Diversification & & \\
\hline & Abandon livestock & 85.0 & 15.0 \\
\hline New breeds & New breeds & 9.0 & 91.0 \\
\hline Terraces & Terrace & 27.0 & 73.0 \\
\hline
\end{tabular}

of strategies. The strategies are categorized into groups depending on their use and relatedness as in Table 4. To determine the socioeconomic and institutional characteristics that influence the choice of response strategies, multivariate probit model was used. The results are presented in Table 3 for choice of crop response strategies.

From Table 6 , the results on correlation coefficients of error terms indicate that there are complementarities (positive correlation) between different response options being used by farmers. The results support the assumption of interdependence between the different adaptation options. A likelihood ratio test based on the log-likelihood values indicate significant correlations $\chi^{2}$ $(91)=306.38$; probability $>\chi^{2}=0.0000$ justifying that the explanatory power of the multivariate probit model had a strong effect.

Households, which exclusively depended on agriculture, were $53 \%$ more likely to introduce new breeds at $1 \%$ significance level and $27 \%$ more likely to use risk management practices at $10 \%$ significance. Farmers who have no other off farm occupation dedicate all their time and resources to agriculture, hence they can, reduce or increase herd size or introduce adaptable species they can also invest in introducing new breeds in order to improve their incomes. Spencer et al. [38] noted that off farm occupation share most of farmers' time farmers pay little attention to their farming activity and focus on off farm activities.
Male-headed households were $48 \%$ more likely to take up crop and herd management practices at $5 \%$ significance level. Male household heads have more access and control over productive resources hence can make decisions on undertaking activities, which require substantial investment in their efforts to curb the effect of climate variability. Introduction of new farm animals require high investments coupled with labor that is more physical hence men are in a better position to provide them on farm labor force in order to adapt them. Male and femaleheaded households perceive and experience climate change in diverse ways because of their distinct socially constructed gender roles, responsibilities, status and identities. This result varies in response strategies with men leaning toward those that need much labor and more long term and require more finance like introducing new animals. This is in line with Atinkut and Mebrat [5] who found that male-headed households have greater preferences to use strategies that require labor, finance and climate information than female-headed households. It is also supported by Epule et al. [16] who found out that generally females are more susceptible or vulnerable to food and water shortages.

Older household heads are $1 \%$ more likely to use intensification strategies, introduce terraces at $5 \%$ significance and risk reduction practices at $10 \%$ significance as response strategies to climate variability. There is higher likelihood of perceiving climate change with increasing 
Table 6 Multivariate probit results for factors affecting the use of crop response practices

\begin{tabular}{|c|c|c|c|c|c|c|c|}
\hline Variable & $\begin{array}{l}\text { Cultural } \\
\text { Coef. }\end{array}$ & $\begin{array}{l}\text { Risk } \\
\text { Coef. }\end{array}$ & $\begin{array}{l}\text { Intense } \\
\text { Coef. }\end{array}$ & $\begin{array}{l}\text { Crop and herd } \\
\text { Coef. }\end{array}$ & $\begin{array}{l}\text { Diverse } \\
\text { Coef. }\end{array}$ & $\begin{array}{l}\text { New breeds } \\
\text { Coef. }\end{array}$ & $\begin{array}{l}\text { Terrace } \\
\text { Coef. }\end{array}$ \\
\hline Occupation & $-0.27(0.33)$ & $0.27(0.16)^{*}$ & $-0.07(0.15)$ & $0.34(0.21)$ & $-0.11(0.18)$ & $0.53(0.20)^{* * *}$ & $-0.14(0.15)$ \\
\hline Gender & $0.26(0.32)$ & $-0.20(0.16)$ & $0.18(0.14)$ & $0.48(0.23)^{* *}$ & $-0.11(0.19)$ & $0.30(0.22)$ & $0.22(0.15)$ \\
\hline Age & $0.02(0.02)$ & $0.01(0.01)^{*}$ & $0.01(0.01)^{* *}$ & $0.01(0.01)$ & $0.00(0.01)$ & $0.00(0.01)$ & $0.01(0.01)^{* *}$ \\
\hline Education & $-0.06(0.22)$ & $0.11(0.10)$ & $-0.11(0.09)$ & $0.21(0.11)^{* *}$ & $-0.05(0.11)$ & $0.30(0.10)^{* * *}$ & $0.14(0.09)^{*}$ \\
\hline Household size & $-0.17(0.08)^{* *}$ & $-0.10(0.04)^{* *}$ & $0.01(0.04)$ & $-0.01(0.05)$ & $-0.01(0.04)$ & $-0.03(0.05)$ & $-0.01(0.04)$ \\
\hline Land size & $0.03(0.07)$ & $0.01(0.03)$ & $0.06(0.03)^{*}$ & $0.10(0.04)^{* * * *}$ & $0.08(0.04)^{*}$ & $-0.05(0.04)$ & $0.01(0.03)$ \\
\hline Weather information & $0.63(0.40)$ & $0.74(0.16)^{* * *}$ & $0.49(0.15)^{* * * *}$ & $0.39(0.22)^{*}$ & $0.34(0.19)^{*}$ & $-0.12(0.20)$ & $-0.06(0.15)$ \\
\hline Extension service & $-0.21(0.38)$ & $0.10(0.16)$ & $0.27(0.15)^{*}$ & $-0.08(0.21)$ & $-0.21(0.18)$ & $0.18(0.20)$ & $0.42(0.15)^{* * *}$ \\
\hline Group membership & $0.51(0.38)$ & $0.14(0.16)$ & $-0.07(0.16)$ & $0.38(0.24)$ & $0.15(0.19)$ & $0.53(0.23)^{* *}$ & $0.12(0.16)$ \\
\hline Credit & $1.15(0.65)^{*}$ & $-0.26(0.17)$ & $0.17(0.16)$ & $-0.15(0.22)$ & $-0.05(0.20)$ & $-0.04(0.20)$ & $0.28(0.16)^{*}$ \\
\hline Distance to market & $-0.07(0.06)$ & $-0.06(0.03)^{* *}$ & $0.03(0.02)$ & $0.07(0.03)^{* *}$ & $-0.08(0.03)^{* * * *}$ & $0.06(0.03)^{*}$ & $0.07(0.03)^{* * * *}$ \\
\hline ward2 & $-0.96(0.34)^{* * *}$ & $-0.62(0.17)^{* * *}$ & $-0.40(0.17)^{* *}$ & $0.22(0.26)$ & $-1.10(0.20)^{* * *}$ & $0.73(0.23)^{* * *}$ & $-0.11(0.17)$ \\
\hline ward3 & $-0.03(0.59)$ & $0.44(0.26)^{*}$ & $-0.72(0.20)^{* * *}$ & $1.48(0.24)^{* * *}$ & $-1.06(0.24)^{* * *}$ & $0.65(0.25)^{* * *}$ & $-0.73(0.25)^{* * * *}$ \\
\hline _cons & $2.32(1.14)^{*}$ & $0.42(0.52)$ & $-0.60(0.48)$ & $-4.09(0.73)^{* * *}$ & $1.88(0.60)$ & $-2.90(0.67)^{* * *}$ & $-1.96(0.48)^{* * *}$ \\
\hline Rho2 & $0.24^{* * * *}$ & & & & & & \\
\hline Rho3 & $0.03^{* * *}$ & 0.01 & & & & & \\
\hline Rho4 & 0.06 & 0.16 & $0.08^{* *}$ & & & & \\
\hline Rho5 & $0.20^{* * *}$ & $0.27^{* * * *}$ & 0.17 & -0.13 & & & \\
\hline Rho6 & 0.05 & $-0.13^{* * *}$ & $-0.17^{* * *}$ & $0.19 *$ & $-0.29 * * *$ & & \\
\hline Rho7 & $0.03^{* *}$ & -0.07 & $0.26^{* * *}$ & $0.07^{* * *}$ & 0.08 & -0.07 & \\
\hline Observations & & & & & & & 392 \\
\hline Log-likelihood & & & & & & & 920.34 \\
\hline Wald $\chi^{2}(91)$ & & & & & & & 306.38 \\
\hline Prob $>\chi^{2}$ & & & & & & & 0.0000 \\
\hline
\end{tabular}

Likelihood ratio test of $r h 021=r h o 31=r h o 41=r h o 51=r h o 61=r h o 71=r h o 32=r h o 42=r h o 52=r h o 62=r h o 72=r h o 43=r h o 53=r h o 63=r h o 7$ $3=$ rho54 $=$ rho64 $=$ rho74 $=$ rho65 $=$ rho75 $=$ rho $>76=0$ : chi2 $(21)=117.229$ Prob $>$ chi $2=0.0000 * * * * * *=$ Significant at $1 \%, 5 \%$ and $10 \%$ significance level, respectively

Figures in parenthesis represent standard errors

age of the head of the household associated with experience, which lets farmers observe changes over time and compare such changes with current climatic conditions. Older farmers are more likely to have more information and knowledge on changes in climatic conditions and crop and livestock management practices. This makes them ready to respond to climate change using different methods. Experienced farmers are usually leaders and progressive farmers in rural communities and are mostly targeted by extension agents and other stakeholders in promoting response adaptation to changing climatic conditions. Mudombi-Rusinamhodzi et al. [26] note that, as household head gets older, more educated and acquire more faming experience; responsiveness to climate variability-induced hazards will increase.

More educated household heads are $30 \%, 21 \%$ and $14 \%$ more likely to introduce new breeds, use crop and herd management, and construct terraces, respectively. There was significant relationship between education level and introduction of new breeds, use of crop and herd management and construction of terraces as response strategies at $1 \%, 5 \%$ and $10 \%$ significance level, respectively. Introduction of new breeds, new farm animals and terrace construction are strategies, which need higher technical expertise. Farmers that are more educated are likely to be more knowledgeable and progressive, hence can easily implement these strategies. Being more educated improves the ability to access information and interpret the information. This may influence uptake of response strategies such as introducing new farm animals and new breeds. Higher level of education may also enhance access to off farm employment. The extra income can be used to invest in terraces, introduce new farm animals and new breeds. Higher education level may also influence farmers' attitudes and decisions, making them more open, rational and able to analyze the benefits of response strategies. Esiobu and Onubuogu [18] found similar results in choosing climate change adaptation options attributed to 
educated farmers having more knowledge on response to climate change strategies. In contrast, Runhaar et al. [35] found that higher education levels and higher cash earnings put farmers in a less vulnerable situation hence they are less likely to respond to climate variability.

Households with many members are $17 \%$ and $10 \%$ less likely to use cultural practices and risk reduction strategies, respectively, at $5 \%$ significance level to reduce the impact of climate variability. Some of the strategies such as water harvesting, early planting, crop rotation and intercropping, use of paddocks, increasing and reducing herd size do not require much labor which may be provided by a large household. More household members increase pressure on the income of the household heads and the farm incomes. This leads to much income being diverted to the consumption expenditure at the expense of being invested in the response practices. Members of a larger household may be tempted to revert to off farm activities in order to get extra income to cater for the increased needs. This leaves them with less time to concentrate on farming activities. However, this contradicts with the findings of Raymond et al. [33] who found that increasing household size by one member increases the probability of adaptation by $1 \%$ and attributed it to having additional household labor, which facilitates adaptation.

Households with large land sizes are $10 \%, 6 \%$ and $8 \%$ more likely to use crop and herd management practices, intensification practices and diversification, respectively, as responses to climate variability. There was significant relationship between land size and use of crop and herd management practices, intensification practices and diversification at $1 \%$ and $10 \%$ significance level, respectively. Large farm size allows farmers to diversify farm enterprises to minimize climatic and agricultural risks. Zero grazing also needs land for pasture and fodder cultivation in order to minimize the production costs. Land is an asset an particularly during the dry spells may be used by farmers to access credit and other resources that can enable the implementation of capital intensive response strategies like zero grazing, planting improved fodder, introduction of new animals. Raymond et al. [33] noted that an additional hectare of land increases the likelihood of adaptation by $6 \%$ among farmers in the middle-income tercile and $2 \%$ among farmers in the highest income tercile because Access to land and property rights are important determinants of adaptation.

Access to weather information increased the likelihood of using risk reduction practices by $74 \%$ and intensification practices by $49 \%$ at $1 \%$ significance level, crop and herd management by $39 \%$ and diversification by $34 \%$ at $10 \%$ significance level. Practices such as staggering planting dates, introducing adaptable species, mulching, reducing herd size and abandoning livestock may depend on prior knowledge of the farmer about the anticipated variability in climate. Access to information on variability is likely to enhance their probability to perceive climate variability, and take up adaptation techniques. If farmers receive information about rainfall, they are more likely to adjust planting time, reduce herd size, perform mulching plant improved fodder or keep browsers depending on the nature of the information. Access to information on climate change enables farmers to make informed agronomic decisions. If the information is reliable, farmers can time their operations, choose what varieties to grow, as well as crop mixes [15].

Households with access to extension services are $42 \%$ and $27 \%$ more likely to use terraces and intensification practices, respectively. The results indicate there is a significant relationship between access to extension and use of terraces and intensification practices at $1 \%$ and $10 \%$ significance level, respectively. Extension agencies act as a link between the innovators (researchers) of the technology and users of that technology. They focus on the provision of training, which improves the skills of household members to improve their own situation and adaptive capacity. Farmers who have significant extension contacts have better chances to be aware of changing climatic conditions and also of the various management practices that they can use to adapt to changes in climatic conditions. Mulching, planting improved fodder, zero grazing and terrace construction are some of the practices that most extension agents encourage farmers to practice because they are considered the basic practices that can be easily implemented by farmers. Extension agents transfer modern agricultural technologies to farmers to help them counteract the negative impact of climate change. Atinkut and Mebrat [5] found that increased extension contacts is likely to increase the probability of the farmer to adapt crop-diversification, soil and water conservation and seasonal migration because farmers who have access to extension services are more likely to be aware of climatic conditions. Aymone [6] also noted that extension on crop and livestock production represent access to the information required to make decision on adaptation to climate change.

Farmers who belonged to a group were $53 \%$ more likely to introduce new breeds to respond to climate variability. There was a significant relationship between group membership and introduction of new farm animals $5 \%$ significance level. In technology adoption, group membership enhances social capital which plays a significant role in information exchange. Information about new farm animals among others can be found through the interaction of different group members who have different experiences. Membership to a group encourages farmers to engage in a united strategies orientation, hence they share 
knowledge and innovative ideas, discuss problems and challenges with others and engage in collaborative decision making. Groups also increase the chances of members accessing credit and hence enhancing their financial muscle to invest in the response strategies. The group platform acts as an interface for information exchange. Moreover, when farmers work in groups, they are likely to be influenced by the actions of their peers, hence they will be motivated to adopt new strategies especially if they see the positive impacts of the strategies on their peers. It is through such groups that the members can also share climate information [42].

Access to credit increases the likelihood of implementing cultural practices by $150 \%$ and terrace construction by $28 \%$ at $10 \%$ significance level. Credit increases finances available to the farmers to take up different response strategies especially those that command substantial investments like water harvesting and irrigation, increased use of organic fertilizer and terrace construction. This is in line with the findings of Nhemachena et al. [29] who found credit to have a positive impact on adaptation strategies. They argued that with more financial and other resources at their disposal, farmers are able to change their management practices in response to changing climatic and other factors. They are able to make use of all the available information they might have on changing conditions both climatic and other socioeconomic factors.

Distance to the market reduces the likelihood of using diversification practices by $6 \%$ at $1 \%$ significance and risk reduction practices by $8 \%$ at $5 \%$ significance. While it increases the likelihood of using terraces by $7 \%$, crop and herd management by $7 \%$ and new farm animals by $6 \%$ at $1 \%, 5 \%$ and $10 \%$ significance level, respectively. Access to markets by smallholder farmers has a strong impact on agricultural production through its influence on the profitability of agricultural output and household incomes. Any surplus incomes obtained may be invested in diversification and risk management technologies provided the required inputs that complement the technologies are also accessible in the markets. Longer distances tend to increase transaction costs, hence minimizing the surplus that can be used in responding to climate variability. This is in line with Spencer et al. [38] who noted that distant farmers have higher transaction cost for acquiring input and output thereby reducing the relative advantage of adopting new technologies. Proximity to market is an important determinant of adaptation, presumably, because the market serves as a means of exchanging information with other farmers [25]. On the contrary, longer distance to the market increases the likelihood of using crop and herd management, new breeds and terraces. Farmers who are further from the market may encounter problems of information asymmetry on both input and output markets.
This may increase the costs incurred by the farmers making them to stagger planting dates in order to reduce risk. On the other hand, farmers may decide to respond by introducing new farm animals and new breeds in order to reduce the costs of accessing from the market. Tesfaye and Seifu [39] found similar results and attributed the remoteness from markets to favor multiple cropping over specialized crop cultivation.

In terms of regional effects, farmers living in $\mathrm{Ng}$ 'arua were significantly likely to introduce new breeds by $73 \%$ as a response to climate variability at $1 \%$ significance level relative to Nyahururu farmers. Nyahururu farmers by contrast were $96 \%, 62 \%$ and $10 \%$ likely to uptake cultural practices, risk reduction and diversification practices, respectively, at $1 \%$ significance level and $40 \%$ likely to uptake intensification practices at $5 \%$ significance level than Ngarua farmers. Ng'arua and Nyahururu are both classified as Mixed Farming (MF) zones Roden et al. [34] but $\mathrm{Ng}^{\prime}$ arua borders Marginal Mixed farming zones which differentiates it from Nyahururu. Farmers in Ng'arua have substantially larger land sizes hence are able to introduce new breeds of animals on the farm. They are mainly wheat and maize farmers which could be used to facilitate access to fodder for new breeds of animals through crop residues. Lack of grazing lands necessitate the need for new breeds that can utilize the available feeds. In Nyahururu farmers mainly plant maize and horticultural crops and had relatively small plots. This makes it easy for them to practice mulching, crop rotation, replanting and increased use of organic fertilizer. There is also need to practice zero grazing because of limited space and promotes simple irrigation for the crops.

Olmoran farmers were $148 \%$ and $65 \%$ likely to adopt crop and herd management practices and introduce new breeds, respectively, as responses to climate variability at $1 \%$ and $44 \%$ likely to adopt risk reduction practices at $10 \%$ significance compared to their Nyahururu counterparts. Nyahururu farmers on the other hand are $72 \%, 10 \%$ and $73 \%$ more likely to uptake intensification, diversification and terraces, respectively, at $1 \%$ significance level. Olmoran is classified as a Marginal Mixed Farming (MMF) zone, while Nyahururu is classified as a Mixed Farming (MF) zone [34]. Olmoran is drier, receives more unreliable rainfall and characterized with more harsh conditions than Nyahururu. This makes more farmers in Olmoran to revert to planting adaptable species, reducing herd sizes, keeping browsers or introducing new animals and breeds which can thrive in the harsh environmental conditions. However, the farmers may not abandon livestock, practice zero grazing or plant improved fodder. This can be attributed to the preservation of cultural and traditional systems of agriculture within Olmoran and also the continuous human wildlife 
conflicts in the region. A report by the Roden et al. [34] noted that some parts of MMF (Olmoran) are still recording deteriorating body condition of livestock due to lack of pasture contributed to by inadequate rain.

\section{Conclusions and policy implications}

The results of the principle component analysis indicate that response to climate variability in the area was mostly through cultural practices, crop and water management and herd management practices. On the other hand use of terraces, soil management, diversification and livestock improvement were the least used strategies.

The results of the multivariate Probit model indicated that access to extension and weather information played an important role toward response to climate variability. Other factors that influenced response to climate variability included gender and education level. In contrast household size had a negative effect on response to climate change while, agro-ecological zones had a mixed effect on the decision of the farmers to undertake specific response strategies.

Therefore, intensifying the sensitization of farmers to seek extension services from both government extension agents and private extension service providers could be an effective way of improving response capacity of farmers to cope with climate variability in the area. Extension agents should provide information targeting climate variability, which will improve their importance to the less educated and less experienced farmers. The extension messages should be presented in simple and understandable forms. Social and physical infrastructure should be improved and institutions dealing with climate-related issues including the meteorology agency be strengthened to increase adaptive capacity. The concerned stakeholders on different ways of responding should enhance Farmer education through constant trainings, seminars and field demonstrations. There is also a need for policies aimed at localized solutions enhancing household level adaptation through the support of department of meteorological service by reporting and alerting households about weather changes in an understandable way so that they can be able to plan for the future when farming.

Acknowledgements The authors would like to acknowledge the financial support from National Commission for Science Technology and Innovation (NACOSTI) who funded this study. Our appreciation also goes to the staff of the Department of Agricultural Economics and Agribusiness Management of Egerton University, enumerators for their valuable contributions. Special thanks go to all households who responded to our questions.

\section{Compliance with ethical standards}

Conflict of interest The authors declare that they have no competing interests.

Ethical approval All procedures performed in studies involving human participants were in accordance with the ethical standards of the institutional and/or national research committee and with the 1964 Helsinki declaration and its later amendments or comparable ethical standards.

\section{References}

1. Adimassu Z, Kessler A, Stroosnijder L (2014) Farmers' strategies to perceived trends of rainfall and crop productivity in the Central Rift Valley of Ethiopia. Environ Dev 11:123-140. https://doi. org/10.1016/j.envdev.2014.04.004

2. Alemayehu A, Bewket W (2016) Local climate variability and crop production in the central highlands of Ethiopia. Environ Dev 19:36-48. https://doi.org/10.1016/j.envdev.2016.06.002

3. Alemayehu A, Bewket W (2017) Determinants of smallholder farmers' choice of coping and adaptation strategies to climate change and variability in the central highlands of Ethiopia. Environ Dev. https://doi.org/10.1016/j.envdev

4. Alemayehu A, Bewket W (2017) Smallholder farmers' coping and adaptation strategies to climate change and variability in the central highlands of Ethiopia. Local Environ 22(7):825-839

5. Atinkut B, Mebrat A (2016) Determinants of farmers choice of adaptation to climate variability in Dera woreda, south Gondar zone, Ethiopia. Environ Syst Res 5(1):6. https://doi.org/10.1186/ s40068-015-0046-x

6. Aymone $\mathrm{G}$ (2009) Understanding farmers' perceptions and adaptation to climate change and variability: the case of the Limpopo basin, South Africa. IFPRI Discussion paper 00849, International Food Policy Research Institute, Washington, DC. http://hdl.handle.net/10568/21663

7. Belderbos R, Carree M, Diederen B, Lokshin B, Veugelers $R$ (2004) Heterogeneity in R\&D cooperation strategies. Int J Ind Organ 22(8-9):1237-1263. https://doi.org/10.1016/j.ijind org.2004.08.001

8. Belderbos R, Carree M, Lokshin B (2004) Cooperative R\&D and firm performance. Res Policy 33(10):1477-1492. https://doi. org/10.1016/j.respol.2004.07.003

9. Beyene $F$ (2016) Land use change and determinants of land management: experience of pastoral and agro-pastoral herders in eastern Ethiopia. J Arid Environ 125:56-63. https://doi. org/10.1016/j.jaridenv.2015.10.001

10. Bowley M, Cooling J, Burditt SL, Brindley DN (1977) The effects of amphiphilic cationic drugs and inorganic cations on the activity of phosphatidate phosphohydrolase. Biochem J 165(3):447-454. https://doi.org/10.1042/bj1650447

11. Chinasho A, Yaya D, Tessema S (2017) The adaptation and mitigation strategies for climate change in pastoral communities of Ethiopia. Am J Environ Prot 6(3):69. https://doi.org/10.11648 /j.ajep.20170603.12

12. De Bruin A, Brush CG, Welter F (2006) Introduction to the special issue: towards building cumulative knowledge on women's entrepreneurship. Entrep Theory Pract 30(5):585-593. https:// doi.org/10.1111/j.1540-6520.2006.00137.x

13. Deressa TT, Hassan RM, Ringler C (2011) Perception of and adaptation to climate change by farmers in the Nile basin of Ethiopia. J Agric Sci 149(1):23-31. https://doi.org/10.1017/S002185961 0000687 
14. Diallo I, Bain CL, Gaye AT, Moufouma-Okia W, Niang C, Dieng MD, Graham R (2014) Simulation of the West African monsoon onset using the HadGEM3-RA regional climate model. Clim Dyn 43(3-4):575-594. https://doi.org/10.1007/s00382-014-2219-0

15. Dinku T, Block P, Sharoff J, Hailemariam K, Osgood D, del Corral $\mathrm{J}$, Cousin R, Thomson MC (2014) Bridging critical gaps in climate services and applications in Africa. Earth Perspect 1(15):1-13. https://doi.org/10.1186/2194-6434-1-15

16. Epule ET, Peng C, Lepage L, Chen Z (2012) Poverty and gender oriented vulnerabilities to food and water scarcity in Touroua, Cameroon. J Hum Ecol 38(2):81-90. https://doi. org/10.1080/09709274.2012.11906477

17. Epule TE, Ford JD, Shuai Lwasa S, Lepage L (2017) Climate change adaptation in the Sahel. Environ Sci Policy 75:121-137. https://doi.org/10.1016/j.envsci.2017.05.018

18. Esiobu NS, Onubuogu GC (2014) Trend, perceptions and adaptation options of Arable crop farmers to climate change in Imo State Nigeria; a multinomial logit approach. World Sci J 5(9):12-24

19. Golob TF, Regan AC (2002) Trucking industry adoption of information technology: a multivariate discrete choice model. Transp Res Part C 10:205-228. https://doi.org/10.1016/S0968 $-090 \times(02) 00006-2$

20. Greene W (2003) Simulated maximum likelihood estimation of the normal-gamma stochastic frontier model. J Prod Anal 19(2):179-190. https://doi.org/10.1023/A:1022853416499

21. Khatri-Chhetri A, Aggarwal PK, Joshi PK, Vyas S (2017) Farmers' prioritization of climate-smart agriculture (CSA) technologies. Agric Syst 151:184-191. https://doi.org/10.1016/j. agsy.2016.10.005

22. Kpadonoua ARB, Owiyo T, Barbierc B, Dentona F, Rutabingwaa F, Kiemada A (2017) Advancing climate-smart-agriculture in developing drylands: joint analysis of the adoption of multiple onfarm soil and water conservation technologies in West African Sahel. Land Use Policy 61:196-207. https://doi.org/10.1016/j. landusepol.2016.10.050

23. Laikipia District Development Plan (2008) Effective management for sustainable economic growth and poverty reduction. Nairobi, Kenya

24. Lin CJ, Jensen KL, Yen ST (2005) Awareness of foodborne pathogens among US consumers. Food Qual Prefer 16:401-412. https ://doi.org/10.1016/j.foodqual.2004.07.001

25. Maddison D (2006) The perception and adaptation to climate change in Africa. CEEPA. Discussion paper No. 10. Centre for Environmental Economics and Policy in Africa. Pretoria, South Africa, University of Pretoria. https://doi.org/10.1596/1813-9450-4308

26. Mudombi-Rusinamhodzi G, Siziba S, Kongo V (2012) Factors affecting smallholder farmers' responsiveness to climate variability induced hazards in Zimbabwe. Afr Crop Sci J 20(2):297-301

27. Mugi-Ngenga EW, Mucheru-Muna MW, Mugwe JN, Ngetich FK, Mairura FS, Mugendi DN (2016) Household's socio-economic factors influencing the level of adaptation to climate variability in the dry zones of Eastern Kenya. J Rural Stud 43:49-60. https ://doi.org/10.1016/j.jrurstud.2015.11.004

28. Ng'ang'a S, Van Wijk MT, Rufino MC, Giller KE (2016) Adaptation of agriculture to climate change in semi-arid Borena, Ethiopia. Reg Environ Change 16(8):2317-2330. https://doi.org/10.1007/ s10113-016-0940-4
29. Nhemachena C, Hassan R, Chakwizira J (2014) Analysis of determinants of farm-level adaptation measures to climate change in Southern Africa. J Dev Agric Econ 6(5):232-241

30. Nzelibe J (1999) Free movement: a federalist reinterpretation. Am Univ Law Rev 49:433

31. Omoyo NN, Wakhungu J, Oteng'i S (2015) Effects of climate variability on maize yield in the arid and semi-arid lands of lower eastern Kenya. Agric Food Secur 4(1):8. https://doi.org/10.1186/ s40066-015-0028-2

32. Paul CJ, Weinthala ES, Bellemare MF, Jeuland MA (2016) Social capital, trust, and adaptation to climate change: evidence from rural Ethiopia. Glob Environ Change 36:124-138. https://doi. org/10.1016/j.gloenvcha.2015.12.003

33. Raymond CM, Bryan BA, MacDonald DH, Cast A, Strathearn S, Grandgirard A, Kalivas T (2009) Mapping community values for natural capital and ecosystem services. Ecol Econ 68(5):13011315. https://doi.org/10.1016/j.ecolecon.2008.12.006

34. Roden P, Bergmann C, Ulrich A, Nüsser M (2016) Tracing divergent livelihood pathways in the drylands: a perspective on two spatially proximate locations in Laikipia County, Kenya. J Arid Environ 124:239-248

35. Runhaar $\mathrm{H}$, Mees $\mathrm{H}$, Wardekker A, van der Sluijs J, Driessen PP (2012) Adaptation to climate change-related risks in Dutch urban areas: stimuli and barriers. Reg Environ Change 12(4):777-790. https://doi.org/10.1007/s10113-012-0292-7

36. Senyolo MP, Long BT, Blok V, Omta O (2017) How the characteristics of innovations impact their adoption: an exploration of climate-smart agricultural innovations in South. Afr J Clean Prod. https://doi.org/10.1016/j.jclepro.2017.06.019

37. Sidibé A (2005) Farm-level adoption of soil and water conservation techniques in northern Burkina Faso. Agric Water Manag 71(3):211-224. https://doi.org/10.1016/j.agwat.2004.09.002

38. Spencer T, Zou S, Ribera T, Colombier M (2015) Mapping issues and options on climate finance in 2015 (No. 08/15). Working papers

39. Tesfaye W, Seifu L (2016) Climate change perception and choice of adaptation strategies: empirical evidence from smallholder farmers in east Ethiopia. Int J Clim Change Strateg Manag 8(2):253-270. https://doi.org/10.1108/IJCCSM-01-2014-0017

40. Tessema YA, Aweke CS, Endris GS (2013) Understanding the process of adaptation to climate change by small-holder farmers: the case of east Hararghe Zone, Ethiopia. Agric Food Econ 1(1):13. https://doi.org/10.1186/2193-7532-1-13

41. World Bank (2010) Kenya - Adaptation to Climate Change in Arid and Semi-Arid Lands (KACCAL) Project. World Bank, Washington, DC

42. Zamasiya B, Nyikahadzoi K, Mukamuri BB (2017) Factors influencing smallholder farmers' behavioural intention towards adaptation to climate change in transitional climatic zones: a case study of Hwedza District in Zimbabwe. J Environ Manag 198:233-239. https://doi.org/10.1016/j.jenvman.2017.04.073

Publisher's Note Springer Nature remains neutral with regard to jurisdictional claims in published maps and institutional affiliations. 